CASE NOTE

\title{
GERMANY $v$ XT (CJEU, 2021): PALESTINIAN REFUGEES, UNRWA AND ARTICLE 1D OF THE REFUGEE CONVENTION
}

\author{
CYNTHIA ORCHARD*
}

TABLE OF CONTENTS

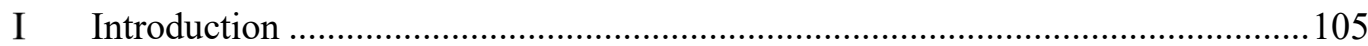

A Alternative Sources of International Protection........................................107

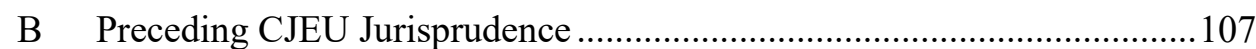

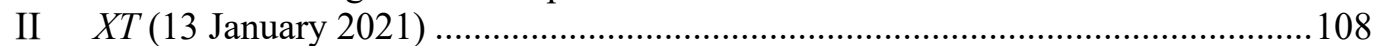

A Summary of Facts and Case History .................................................. 108

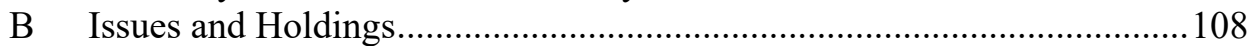

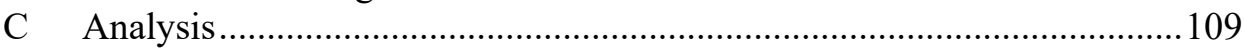

III Article 1D's Recent Application in Domestic Jurisdictions - Brief Examples... 110

IV Considerations Relating to Current Events ……................................................... 112

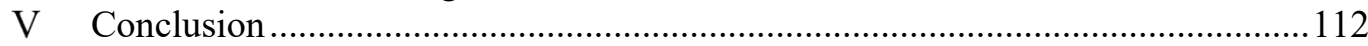

\section{INTRODUCTION}

This case note focuses on the preliminary ruling of the Court of Justice of the European Union ('CJEU') issued on 13 January 2021 in the Bundesrepublik Deutschland $v X T$ ('XT'). ${ }^{1}$ The case concerns a stateless person of Palestinian origin and whether he is a refugee pursuant to art 1D of the 1951 Convention Relating to the Status of Refugees ('1951 Refugee Convention'). ${ }^{2}$ The applicant mainly lived in Syria but lived in Lebanon for two years. The case's key issue is whether the fields of operation of the United Nations Relief and Works Agency for Palestine Refugees in the Near East ('UNRWA') should be considered as a whole, and what this means for exclusion or inclusion under art 1D. The German Federal Administrative Court also requested clarification of the term 'habitual residence', but the Court declined to address this. ${ }^{3}$

* Cynthia Orchard (BA, JD, MSt) is an independent consultant, human rights lawyer, trainer, and policy advocate. She has worked with UNHCR, several NGOs and the University of Oxford Refugee Studies Centre, and is a member of the European Network on Statelessness. The introduction to this case note is based in part on an article by the author, which was previously published by the Immigration Law Practitioners' Association. See 'Palestinian Refugees: How Article 1D of the Refugee Convention Applies’ (25 February 2016, available to ILPA members at https://ilpa.org.uk/?s=cynthia+orchard). Thanks to Judith Carter for comments on a draft of this case note.

1 Bundesrepublik Deutschland $v$ XT ['Federal Republic of Germany $v$ XT'] (Court of Justice of the European Union, C-507/19, ECLI:EU:C:2021:3, 13 January 2021) ('XT').

2 ibid; Convention Relating to the Status of Refugees, opened for signature 28 July 1951, 189 UNTS 150 (entered into force 22 April 1954) ('1951 Refugee Convention').

$3 X T(\mathrm{n} \mathrm{1)}$ [35], [81]. This case note will not further discuss this issue, though it certainly merits attention elsewhere. 
Approximately 5 to 8 million Palestinian refugees constitute one of the longestpersisting and largest refugee populations in the world. ${ }^{4}$ In 1949, following the partition of Palestine, the United Nations established UNRWA, with a mandate to assist Palestinian refugees. ${ }^{5}$ UNRWA operates in five areas: Lebanon, Jordan, Syria, Gaza, and the West Bank. Its work has expanded to include protection, particularly since 2012.6

The drafters of the 1951 Refugee Convention included art 1D to address, in part, the United Nations' responsibilities to Palestinian refugees. Article 1D's first clause excludes persons who are receiving protection or assistance from a UN agency other than the Office of the United Nations High Commissioner for Refugees ('UNHCR'). This is followed by an inclusion clause stating that if such protection or assistance ceases, the persons concerned are automatically entitled to the benefits of the Convention.

1951 Refugee Convention, art 1D states:

This Convention shall not apply to persons who are at present receiving from organs or agencies of the United Nations other than the United Nations High Commissioner for Refugees protection or assistance.

When such protection or assistance has ceased for any reason, without the position of such persons being definitively settled in accordance with the relevant resolutions adopted by the General Assembly of the United Nations, these persons shall ipso facto be entitled to the benefits of this Convention.

4 UNRWA estimates that it assists approximately 5.6 million Palestine refugees. See UNRWA, 'Who We Are', United Nations Relief and Works Agency for Palestine Refugees in the Near East (Web Page) <https:/www.unrwa.org/who-we-are\#mm-2>; BADIL estimates there are 7.94 million Palestinian refugees in the world. See BADIL, 'FAQ', BADIL Resource Centre for Palestinian Residency \& Refugee Rights (Web Page) Q1.1 $<$ http://www.badil.org/en/publication/faq.html\#: : :text=Among $\% 20$ them $\% 20 \mathrm{were} \% 20 \mathrm{at} \% 2$ 0least,and $\% 20760 \% 2 \mathrm{C} 000 \% 20$ internally $\% 20$ displaced $\% 20$ persons.\&text $=344 \% 2 \mathrm{C} 599 \% 20$ (3.9\%25),Most $\% 20$ Palestinian\%20refugees\%20(approximately $\% 2079 \% 20$ percent,live $\% 20$ outside $\% 20$ UNRWA's $\% 2058 \% 20$ camps $>$.

5 In this period, Palestine was partitioned and the State of Israel established, followed by related armed conflict, occupation of Palestinian territory, and the forced exodus of Palestinians. See Future Government of Palestine, GA Res 181(II), UN Doc A/RES/181(II) (29 November 1947); For a brief summary of this history, see United Nations, 'History of the Question of Palestine', United Nations: The Question of Palestine (Web Page) $<$ https://www.un.org/unispal/history/>.

6 The United Nations Conciliation Commission for Palestine ('UNCCP') was established in 1948, with a mandate including legal protection for Palestinians. UNCCP still exists, but it has been largely inactive and unable to fulfil most of its mandate since the 1950s. The UN also established UNHCR in 1950, mandated to provide protection and assistance globally to refugees (and since 1974, stateless persons), but not including Palestinians in UNRWA's area of operation. See UNCCP's most recent annual report, saying it had 'nothing new to report', United Nations Conciliation Commission for Palestine, UN Doc A/75/305 (11 Aug 2020); Palestine: Progress Report of the United Nations Mediator, GA Res 194(III), UN Doc A/RES/194(III) (27 November 1948); Assistance to Palestine Refugees, GA Res 302(IV), UN Doc A/RES 302(IV) (7 December 1949); Assistance to Palestine Refugees, Ga Res 70/83, UN Doc A/Res/70/83 (15 December 2015); Operations of the United Nations Relief and Works Agency for Palestine Refugees in the Near East, GA Res 70/85, UN Doc A/RES/70/85 (15 December 2015). See also Susan Akram and Nidal al-Azza, Closing Protection Gaps: Handbook on Protection of Palestinian Refugees in States Signatories to the 1951 Refugee Convention (BADIL Resource Centre for Palestinian Residence and Refugee Rights, 2015) 34-37; Guy Goodwin-Gill and Jane McAdam, The Refugee in International Law (Oxford University Press, 3rd ed, 2007), 436-38; UNRWA, 'What We Do', United Nations Relief and Works Agency for Palestine Refugees in the Near East (Web Page) $<\mathrm{https}$ ://www.unrwa.org/what-we-do/protection>; Lance Bartholomeusz, 'UNRWA's mandate at Sixty', (2009) 28(2-3) Refugee Survey Quarterly 452, 466-69. This case note will refer mainly to UNRWA assistance, rather than protection, for brevity. 
Unfortunately, government decision-makers and judges around the world frequently have been ignorant of or misapplied art 1D, which at times has left Palestinians unable to access protection. ${ }^{7}$

\section{A Alternative Sources of International Protection}

Some Palestinians are refugees under art 1A of the Refugee Convention, based on a well-founded fear of persecution for a Convention reason. Some stateless Palestinians may also be protected under complementary protection or other human rights law, or pursuant to the 1954 Convention relating to the Status of Stateless Persons ('1954 Convention'). However, even in the relatively few countries that have adopted statelessness determination procedures, there are sometimes significant barriers to stateless Palestinians accessing protection through this route. ${ }^{8}$ These alternatives are beyond the scope of this case note.

\section{B Preceding CJEU Jurisprudence}

The CJEU first considered art 1D in 2010 in Bolbol v Bevándorlási És Állampolgársági Hivatal ${ }^{9}$ holding that the words 'at present' mean the present day, rather than the date the 1951 Refugee Convention was signed. Further, Palestinians who have registered with or used UNRWA services are entitled to protection under art 1D (and its parallel in the 2004 EU Qualification Directive ${ }^{10}$ ) if they are no longer receiving UNRWA assistance; however, Palestinians who have never registered nor received UNRWA assistance cannot be included under art 1D. ${ }^{11}$

Two years later, in El Kott v Bevándorlási És Állampolgársági Hivatal, ${ }^{12}$ the CJEU confirmed its holdings in Bolbol and found that persons who previously received UNRWA assistance are excluded from refugee status unless that assistance has ceased for reasons 'beyond the control' of the applicant. ${ }^{13}$ Where UNRWA's assistance has thus ceased, and other exclusion clauses are not applicable, the applicant is automatically (ipso facto) entitled to refugee status. ${ }^{14}$

$7 \quad$ See Closing Protection Gaps (n 6).

8 For examples from the UK, see EIN, 'Statelessness in Practice: Implementation of the UK Statelessness Application Procedure', Electronic Immigration Network (News Article, 10 July 2018) <https://www.ein.org.uk/news/liverpool-law-clinic-examines-implementationuks-statelessness-application-procedure $>$.

9 Bolbol v Bevándorlási És Állampolgársági Hivatal ['Bolbol v Office of Immigration and Nationality'] (Court of Justice of the European Union, C-31-09, ECLI:EU:C:2010:351, 17 June 2010).

10 Council Directive 2004/83/EC of 29 April 2004 on Minimum Standards for the Qualification and Status of Third Country Nationals or Stateless Persons as Refugees or as Persons Who Otherwise Need International Protection and the Content of the Protection Granted [2004] OJ L 304/12.

11 See also Closing Protection Gaps (n 6) ix-xii.

12 El Kott, A Radi and Ismail v Bevándorlási És Állampolgársági Hivatal ['El Kott, A Radi and Ismail v Office of Immigration and Nationality'] (Court of Justice of the European Union, C364/11, ECLI:EU:C:2012:826, 19 December 2012).

13 ibid [47], [59], [63].

14 ibid [81]. See also United Nations High Commission for Refugees, Guidelines on International Protection No. 13: Applicability of Article 1D of the 1951 Convention relating to the Status of Refugees to Palestinian Refugees, UN Doc HCR/GIP/17/13 (December 2017) 3. 
In a third case interpreting art 1D, Serin Alheto $v$ Zamestnik-predsedatel na Darzhavna agentsia za bezhantsite, ${ }^{15}$ the CJEU found that art $1 \mathrm{D}$ must be considered prior to art 1A of the Refugee Convention. Registration with UNRWA did not necessarily mean that the applicant could access sufficient protection in an UNRWA area. ${ }^{16}$ However, Palestinians are not included under art 1D if they could be admitted to any area where they could access effective UNRWA protection/assistance and could live there in safe and dignified conditions for as long as necessary, without being subject to refoulement.

\section{II $\quad X T(13$ JANUARY 2021)}

The latest CJEU case relating to art $1 \mathrm{D}, X T$, expands on this previous jurisprudence.

\section{A Summary of Facts and Case History}

XT is a stateless Palestinian born in Syria in 1991. He is registered with UNRWA and grew up in Yarmouk Refugee Camp in Damascus. He lived in Lebanon from 2013 to 2015 and worked in casual jobs. He returned to Syria as he could not get a residence permit in Lebanon and feared expulsion. He left Syria after a few days, due to the harsh situation there, including the then-ongoing civil war. At that time, Palestinians were banned from entering Jordan and Lebanon. ${ }^{17}$

XT travelled to Germany and applied for international protection in December 2015. The Federal Office for Migration and Refugees refused him refugee status but granted subsidiary protection in August 2016. On appeal, the Administrative Court found that XT was entitled to refugee status, based on a fear of persecution. ${ }^{18}$ The Higher Administrative Court upheld this outcome, finding that XT met the requirements of art $1 \mathrm{D}$, as he had previously received UNRWA assistance but it had ceased, for reasons beyond his control. ${ }^{19}$ On further appeal, the German Federal Administrative Court referred the case to the CJEU for a preliminary ruling - the subject of this note.

\section{B Issues and Holdings}

The key issue for the CJEU was whether, in relation to art 1D, UNRWA's area of operation should be understood as five separate 'fields' or as a whole. ${ }^{20} \mathrm{In}$ considering whether UNRWA's assistance has ceased, should the German authorities consider only the UNRWA field of operation where the applicant most recently lived, or should they consider whether the applicant could return to

15 Serin Alheto $v$ Zamestnik-predsedatel na Darzhavna agentsia za bezhantsite ['Serin Alheto $v$ Deputy Chairman of the State Agency for Refugees'] (Court of Justice of the European Union, C-585/16, ECLI:EU:C:2018:584, 25 July 2018).

16 ibid [90].

$17 X T$ (n 1) [19]-[21].

18 ibid [23]-[24]. The judgment appears to accept that XT faced a risk of arrest and/or other persecution if he returned to Syria for reasons relating to his departure, application for asylum, and residence abroad, so the considerations relating to return were with respect to Lebanon.

19 ibid [25].

20 ibid [29]-[30]. 
another field of UNRWA operation? If the latter, which areas should be considered, and on what criteria? 21

The CJEU made two key holdings:

1) National authorities should consider 'all the fields of UNRWA's area of operations which a stateless person of Palestinian origin who has left that area has a concrete possibility of accessing and safely remaining therein'; ${ }^{22}$

2) UNRWA's assistance cannot be considered to have ceased where the applicant departed from a field of UNRWA operation (in which their safety was at risk and UNRWA was unable to provide assistance), but had previously travelled to that field from another field of UNRWA operation (where their safety was not at risk and they could have received assistance from UNRWA), in circumstances where they could not have reasonably expected to receive UNRWA assistance in the first field, nor to have been able to return at short notice to the second field. ${ }^{23}$

The Court clarified that when assessing possible entry to an UNRWA area, asylum authorities should consider, for example: whether the applicant has a residence permit; family ties; former residence; why they left a particular area; and relevant declarations or practices of authorities in the areas concerned. However, none of these considerations are necessarily definitive on their own. ${ }^{24}$ The Court observed that the authorities in the country of asylum have the responsibility to determine whether an applicant meets the pertinent criteria. However, they noted that XT could not obtain a residence permit in Lebanon and left the country in the context of increased deportations of Palestinians from Lebanon to Syria. All things considered, his departure from Lebanon did not seem 'voluntary'. ${ }^{25}$

\section{Analysis}

The finding that UNRWA's five fields of operation should be treated as one area creates additional evidentiary challenges for some applicants; but it is not necessarily fatal to most art 1D cases. It is still possible that an applicant could show that they do not have a right of residence, could not live in safety and dignity in any UNRWA field of operations, and that UNRWA assistance has ceased for reasons beyond their control. ${ }^{26}$

With respect to the second finding, for various reasons, the history of a Palestinian refugee travelling from one UNRWA field of operation to another should largely be considered irrelevant in determining exclusion. The Court's

21 ibid [31].

22 ibid [67], [82(1)].

23 ibid [82(2)].

24 ibid [58]-[62].

25 ibid [74], [78]-[79].

26 See UNHCR, Statement on the Interpretation and Application of Article $1 D$ of the 1951 Convention and Article 12(1)(a) of the EU Qualification Directive Issued in the Context of the Preliminary Ruling Reference to the Court of Justice of the European Union from the Bundesverwaltungsgericht (Germany) lodged on 3 July 2019 - Federal Republic of Germany $v X T$ (C-507/19) (UNHCR Statement 18 Aug 2020) [24]. The statement asserts that applicants should only be assessed with respect to UNRWA fields of operation in which they had previously lived, rather than all five fields. 
interpretation of this issue means that some Palestinians may be denied protection and left in limbo, without any status. They would be unable to leave the country in which they sought asylum if, at the time of status determination, their circumstances were such that they cannot return to any part of UNRWA's area of operation. In the present case, as noted, the applicant's departure from Lebanon should not be considered to have been voluntary. With different facts, there could be a different result. A better approach would be for decision-makers to consider whether the applicant, at the time of refugee status determination, could or could not access UNRWA assistance that would allow them to live in safety and dignity, in any field of UNRWA operations. If they could not, for reasons beyond their control, then UNRWA assistance should be considered to have ceased, triggering the inclusion clause of art 1D and automatic acknowledgement as a refugee.

As UNHCR emphasises, 'Palestinian refugees who fall within the scope of Article 1D are persons whom the international community has already recognised as refugees' ${ }^{27}$ The aim of the inclusion clause is to maintain their protection. Where an applicant left an UNRWA field of operation voluntarily but later is unable to return to any UNRWA area for reasons beyond their control, UNRWA protection or assistance has ceased. ${ }^{28}$

It would have been helpful if the Court had elucidated the concept of dignity and expanded on its observation that XT could not obtain a residence permit in Lebanon. Palestinians often have no permanent residence - only 'tolerated stay' or temporary permission based on employment, in UNRWA's area of operation and throughout the Middle East and North Africa. In some places, they face significant restrictions on their activities and access to official procedures. In such situations, their status remains precarious, and they should not be considered to be living in that place in safety and dignity for as long as is 'necessary'.29 The Court does not clarify what it means to live in dignity, and this may be the subject of future litigation.

\section{ARTICLE 1D's RECENT APPLICATION IN DOMESTIC JURISDICTIONS -}

\section{BRIEF EXAMPLES}

In some countries, recent jurisprudence has generally followed the El Kott approach, but with varying results. In 2020, in case number $N L 20.6600,{ }^{30}$ an Amsterdam District Court found that UNRWA could not meet the needs of the appellant and his family in Gaza, and UNRWA assistance had ceased for reasons beyond the applicant's control; therefore, he should be granted refugee status.

Similarly, a 2019 judgment of the New Zealand Immigration and Protection Tribunal, $A E$ (Lebanon), ${ }^{31}$ found that the appellant was a refugee pursuant to art 1D. The Tribunal considered the appellant's serious medical conditions and UNWRA'S inability to fund the required medical treatment or provide financial support sufficient to prevent 'abject poverty'. ${ }^{32}$

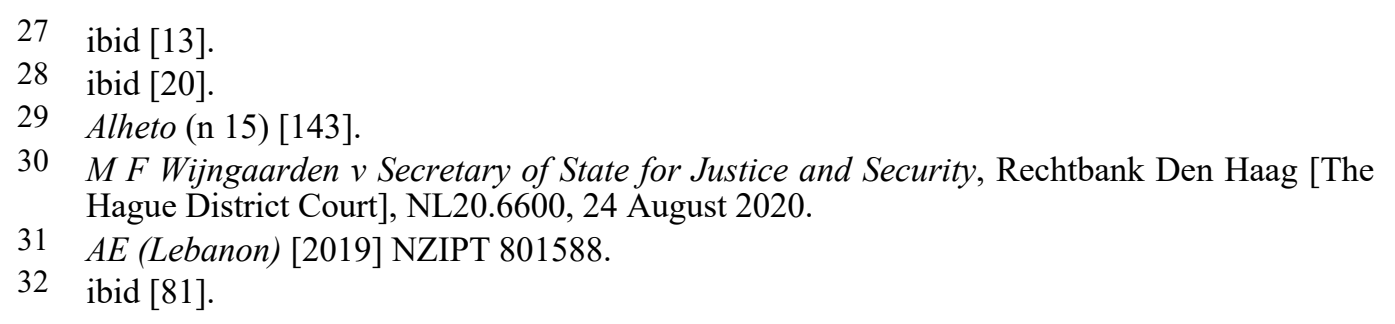


Also in 2019, France's highest court (the Conseil d'Etat) issued its judgment in case no. 427017,33 involving a Palestinian woman who had lived in a refugee camp in Lebanon before going to France. The Court set out the criteria that French authorities must consider in cases relating to the 1954 Convention involving persons who had previously lived in an UNRWA area, including: the reasons why the applicant had lost the 'effective benefit' of UNRWA'S assistance, whether the applicant is unable to return to their place of former habitual residence, and factors relating to their private or family life under art 8 of the European Convention on Human Rights. ${ }^{34}$ Although this case was decided in relation to the 1954 Convention, it seems likely that similar factors would be considered relevant in relation to art 1D of the 1951 Refugee Convention.

In the United Kingdom, a 2019 case, Nader ${ }^{35}$ concerned a Palestinian born and raised in Saudi Arabia. He moved to Lebanon to study for a year, then returned to Saudi Arabia where he was abused and deported back to Lebanon. The applicant was registered with UNRWA and stayed with his grandmother in a refugee camp during part of his time in Lebanon. The Upper Tribunal generally followed the El Kott approach in terms of the factors it considered material, observing that it appeared the applicant had twice departed from Lebanon voluntarily, and there was no evidence that the applicant would be refused entry into Lebanon or face human rights violations there. The applicant had not demonstrated that UNRWA assistance had ceased for reasons beyond his control. ${ }^{36}$ From the decision, it appears that no evidence had been submitted showing that the applicant could not live in dignity in Lebanon.

As noted, however, art 1D is sometimes misunderstood. In another 2019 UK case, $O J,{ }^{37}$ concerning a Palestinian from Gaza, the Upper Tribunal took a flawed approach. The Upper Tribunal Judge held that there was a risk of serious harm in Gaza, which was documented in an expert report, but only allowed the appeal on humanitarian protection grounds. The Judge incorrectly stated that art 1D applied to exclude the applicant as he was 'presently receiving protection from UNRWA'38 [factually incorrect as the applicant was in the UK] without considering the inclusion clause, the El Kott approach, or either UNHCR's or the Home Office's guidance on art 1D. ${ }^{39}$

33 Conseil d'État [French Administrative Court], 24 December 2019, reported in Rec Lebon ('Case no. 427017'). For a helpful summary in English, see Giulia Bittoni, 'Can a Palestinian Refugee Enjoy the Status of a Stateless Person? A French Perspective' European Network on Statelessness (Blog Post, 13 Mar 2020) <https://www.statelessness.eu/updates/blog/canpalestinian-refugee-enjoy-status-stateless-person-french-perspective $>$. Case no. 427017 (n 33) [4].

Mr Abdul Aziz Nader v Secretary of State for the Home Department [2019] UKAITUR PA113132018, [5].

ibid [30]-[35].

OJv Secretary of State for the Home Department [2019] UKAITUR PA093312018.

ibid [19].

The UK Government has published guidance regarding the application of Article 1D, which generally follows the El Kott approach: Asylum Policy Instruction: Statelessness and Applications for Leave to Remain (Guidance, Version 2.0, UK Home Office 2016). A query by the author to an online forum for legal practitioners in the UK (the Refugee Legal Group) in January 2021 brought several responses from practitioners, noting that they have recently worked on or are currently working on Palestinian asylum cases in which Article 1D was ignored or misapplied, by Home Office decision-makers, judges, and/or the applicant's previous legal representative. 


\section{CONSIDERATIONS RELATING TO CURRENT EVENTS}

The inability to travel to some destinations, due to COVID-19 or border closures for security or political reasons, may be a material consideration in establishing that an applicant cannot return to an UNRWA area for reasons beyond their control.

Another important factor that may affect the future of art 1D jurisprudence is UNRWA's ability to continue functioning, and in which circumstances. For years, despite significant successes, UNRWA has been unable to adequately meet some needs of the people it serves, due to resource constraints. The US discontinuation of UNRWA funding in 2018 had a severe impact, but it is likely that President Joe Biden will resume major US contributions to UNRWA. ${ }^{40}$

\section{CONCLUSION}

Following $X T$, if a Palestinian refugee could live in safety and dignity in any part of UNRWA's area of operation, they will be excluded from the benefits of the Refugee Convention under art 1D. This will make it more evidentially challenging for some Palestinian refugees to prove that they merit protection under art 1D and will likely result in exclusion of some Palestinian refugees who merit protection. Prior voluntary travel from one field of UNRWA operation to another may also lead to exclusion in some cases. This seems unnecessary and likely to result in problematic situations; for example, where a Palestinian has voluntarily travelled from Jordan to Syria but cannot return, either to a life of dignity or at all, to any part of UNRWA's area of operations, for reasons beyond their control. It is hoped that domestic courts and future CJEU jurisprudence will clarify that the inability to return to an UNRWA area and live in safety and dignity are the material factors in this consideration, rather than prior voluntary travel from one UNRWA field to another.

40 'Countries Raise \$130 million for UNRWA and Commit Long-Term Support to Palestine Refugees' United Nations Relief and Works Agency for Palestine Refugees in the Near East (Press Release, 23 June 2020) <https://www.unrwa.org/newsroom/press-releases/countriesraise-130-million-unrwa-and-commit-long-term-support-palestine>. Specific details of amounts were not publicly available at time of writing, however. See Mayaan Lubell and Rami Ayyub, 'Analysis: What will survive of U.S.-Middle East policy under Biden?' Thomson Reuters (News Article, 20 Jan 2021) <https://www.reuters.com/article/us-usatrump-legacy-mideast-analysis-idUSKBN29P1RB >; 'Biden Administration to Restore Aid to Palestinians' BBC News (News Article, 27 January 2021) $<$ https://www.bbc.com/news/world-middle-east-55824227>. 